\title{
АНАЛІТИЧНІ МЕТОДИ МОДЕЛЮВАННЯ У НАВЧАЛЬНІЙ ДІЯЛЬНОСТІ МАЙБУТНІХ СПЕЦІАЛІСТІВ МИСТЕЦТВОЗНАВСТВА
}

\section{Слободянюк Т. Б.}

\section{ВСТУП}

Актуальність питання зумовлена тим, що сучасна система освіти передбачає принципово нові підходи до підготовки майбутніх фахівців. Сучасний етап розвитку України характеризується змінами в усіх галузях суспільства, держава переходить до моделі інноваційного розвитку і потребує відповідального особистісного ставлення кожного учасника до цих перетворень. Важливо формувати вміння комплексного застосування знань, їх синтезу, переносу ідей і методів із однієї науки в іншу, мотиваційне усвідомлення значення знань за фахом, інтерес до фахової діяльності, усвідомлення життєвих цілей, спрямованість на самореалізацію. Актуальність зумовлена інтеграційними тенденціями у світовому освітньому просторі й активним розвитком інформацій, у яких значне місце посідають педагогічні інновації, модернізація змісту і структури освіти, реалізація творчих ідей та освітніх ініціатив, формуванням якостей лідера інноваційних перетворень у контексті завдань, поставлених перед освітою Національною доктриною розвитку освіти, Законами України «Про вищу освіту», «Про інноваційну діяльність» та іншими нормативноправовими актами. Особливе місце в загальнодержавній системі освіти України посідають вищі навчальні заклади. Однією зі складових частин комплексної гуманітарної підготовки студентів $\epsilon$ дисципліна «Основи психології та педагогіки», що потребує осучаснення навчання і нових інноваційних підходів. Навчальні курси з педагогіки та психології за застосування різних інноваційних методик сприяють розширенню педагогічних можливостей викладачів вищих навчальних закладів. У системі освіти дедалі активніше застосовуються такі поняття, як «інноваційний процес», «інноваційна діяльність», «інноваційна технологія», «моделювання» та ін. Завдання вищої школи зумовлене сьогодні тенденціями особистісно-орієнтованого навчання й успішно вирішується за допомогою інноваційних зв'язків. Пропонується PR-схема реформ у освіті на найближчі 10 років у напрямах управління освітою та фінансування, враховуючи сучасний стан впровадження реформ, які суттєво змінюють стиль навчальної роботи, переконуючи 
кожного (викладачів, вчителів, студентів та учнів) у перевагах для них особисто.

Аналіз філософської, соціологічної, педагогічної, психологічної літератури та дисертаційних досліджень свідчить про посилення уваги науковців до інноваційної діяльності, підвищення професійного рівня та компетентності педагогічних працівників. Ці принципи лежать у площині та в основі творчого розвитку як вимоги до будь-якої діяльності людини за сучасних умов, враховуючи стан впровадження реформ (соціальних, економічних, політичних), які примушують суттєво змінювати стиль роботи викладачів, студентів і всіх, хто працює у сфері вищої освіти. У педагогічній діяльності викладача вищого навчального закладу переважає вузькоспеціальна компетентність, а його професіоналізм вимагає осмислення широкого спектру проблем, пов'язаних із інтенсифікацією навчально-виховного процесу.

Індивідуалізація навчання у вищих навчальних закладах у педагогічній енциклопедії трактується як організація навчально-виховного процесу, за якої вибір способів i прийомів навчання враховує індивідуальні риси студентів, рівень розвитку здібностей ${ }^{1}$. У підготовці фахівців XXI ст. важливо, поряд із орієнтацією навчання на конкретну діяльність, формувати вміння комплексного застосування знань, їх синтезу, переносу ідей і методів з однієї науки в іншу.

Актуальні сьогодні завдання щодо формування навички роботи студентів над навчальними проєктами у розподілених командах. Навчальна програма не фокусується на певній технології, а дає широке розуміння використання сучасної ІТ-галузі, модульна система програми дає слухачам можливість скласти персональний навчальний план, поєднавши обов'язкові дисципліни зі спеціалізаціями за вибором, та орієнтується на особистісно-орієнтоване навчання ${ }^{2}$.

\section{1. Аналіз ефективності застосування інноваційних методів навчання}

Одним зі шляхів модернізації освітньої системи України $\epsilon$ впровадження у навчальний процес ВНЗ інноваційних педагогічних технологій i методів, що дозволяють суттєво урізноманітнити організаційні форми їх проведення. У навчальній психології активно використовують методи теоретичного аналізу, до яких належить моделювання. Це робить навчання сучасним, цікавим i підвищує ефективність навчальної роботи. Моделювання у вигляді образнологічних схем за аналогією споріднене 3 комп'ютерним баченням логіки взаємозв'язків психологічних явищ. Моделювання

\footnotetext{
${ }^{1}$ Педагогічна енциклопедія. Москва, 1965. Т. 2. С. 201.

${ }^{2}$ Слободянюк Т.Б. Якість підготовки фахівців та ії відповідність європейським стандартам освіти. Науковий часопис / НПУ імені М.П. Драгоманова, 2010. С. 132.
} 
використовують у навчальних техніках «відтворення змісту» та «відтворення логіки пізнання» 3 обгрунтуванням сутності змістових характеристик. Моделювання як відтворення змісту сутнісних ознак полягає в побудові «образу-моделі» психологічного явища або процесу, що характеризує систему природних, соціальних і духовних відносин, ціннісно-смислову сферу засобами «художнього аналізу». Однією 3 найбільш поширених організаційних форм $є$ традиційні інтегровані навчальні заняття: лекції, семінари, практичні роботи, колоквіуми, спецкурси, спецсемінари. На них може бути застосована систематизація навчального змісту за допомогою схем, конструювання і моделювання сутнісних елементів і зв'язків, динамічних елементів.

Принципи включення єдиного циклу до творчого розвитку студентів необхідні як вимоги до будь-якої діяльності людини за сучасних умов. Різні варіанти використання цих понять можна зустріти й у зарубіжній педагогіці. У США поняттям «індивідуалізація» зазвичай охоплюються будь-які форми та методи обліку індивідуальних особливостей учнів.

Психологічний принцип творчого самовдосконалення особистості на підставі теоретико-методологічного аналізу й оновлення філософського принципу творчої самодіяльності суб'єкта був запропонований на початку минулого століття С.Л. Рубінштейном. Застосування аналітичних методів i прийомів стимулює продуктивність мислення за рахунок розширення індивідуального досвіду в навчальній діяльності студентів. Під час вивчення особливостей і специфіки розгортання особистісної рефлексії та рефлексії фахової діяльності студентів виявлено, що ефективним шляхом розвитку рефлексивної сфери $\epsilon$ впровадження в навчальний процес програми розвитку професійної рефлексії, побудованої за принципами інтегрованої організації навчальної діяльності на засадах суб'єктсуб'єктної взаємодії 3 викладачами, високого рівня проблемності, інтегративності й адекватного відображення суттєвих характеристик професійного середовища.

Технологічні особливості в побудові «образу-моделі» та створення образно-логічних схем у напрямах теоретичного вивчення 3 основ психології та педагогіки як навчальної дисципліни допомагає психологічно підготуватися до майбутньої діяльності.

Моделювання образно-логічних схем у навчальній діяльності студентів за використання певних методик i технологій дозволяє отримати якісні педагогічні результати саме у майбутніх спеціалістів мистецтвознавства. Дослідженнями I.Е. Унт розкрито суть поняття індивідуалізації. Індивідуальне навчання вона бачить як форму, модель організації навчального процесу, за якої: 1) учитель взаємодіє лише з одним учнем; 2) один учень взаємодіє лише із засобами навчання (книгами, комп'ютером і т. п.). Головним в індивідуалізації навчанні $\epsilon$ те, що воно дозволяє повністю адаптувати зміст, методи та темпи 
навчальної діяльності до його особливостей, стежити за кожною операцією у вирішенні конкретних завдань; стежити за рухом від незнання до знання, вчасно вносити необхідні корективи у діяльність, пристосовувати їх, контролювати. Це дозволяє тому, хто навчається, контролювати витрати своїх сил, працювати в оптимальний для себе час, досягати високих результатів навчання ${ }^{3}$.

Оскільки наші студенти - майбутні спеціалісти 3 мистецтвознавства i мають фахову творчу спеціалізацію (це майбутні скульптори, живописці, кіносценаристи, архітектори), то наше завдання - залучити їхні творчі можливості в навчальному процесі. Застосування інноваційних методів навчання дозволяе їм в образно-логічних схемах відображати в активній формі зміст навчального матеріалу. Технологія індивідуалізованого навчального процесу, за якої індивідуальний підхід та індивідуальна форма навчання $є$ пріоритетними, забезпечують можливість творчого застосування знань у моделюванні образнологічних схем у навчальній діяльності студентів, розвивають спостережливість, асоціативний тип мислення, вміння запитувати й аналізувати, порівнювати, інтерпретувати, критично оцінювати отримані схеми. За сучасних умов головною формою індивідуалізації навчання $є$ організація самостійної навчальної роботи в аудиторіях чи позааудиторно. На думку Н.Е. Гронлунд, це проявляється в таких варіантах: від мінімальної модифікації у груповому навчанні до повністю незалежного навчання; варіювання темпу навчання, цілей навчання, методів навчання, навчального матеріалу, необхідного рівня успішності; використання індивідуалізованого навчання 3 усіх досліджуваних предметів, із частини предметів, в окремих частинах навчального матеріалу або ж окремими студентами. До цих можливостей додаються адміністративні стратегії - це формування різних творчих груп на підставі загальних ознак студентів. Уявлення про знання можна назвати «пізнавальною позицією» за емпіричною та теоретичною частинами роботи. Дж. де Тагле, котрий запропонував інтегративне навчання, вказував, що основний механізм свідомості, який бере участь у процесі пізнання, враховується опосередковано, через наявність інтенціональних зв'язків (номінації, референції, значення та ін). Об'єкт може розглядатися як елемент у структурі самого знання (ідеальний об'єкт) або як матеріальна дійсність віднесення знань (реальність). Дж. Перрі ввів термін «множинність» як досвід декількох суперечливих відповідей i альтернативу консервативному досвіду - прості, чіткі, однозначні відповіді ${ }^{4}$.

${ }^{3}$ Унт И. Индивидуализация и дифференциация обучения. Москва : Педагогика, 1990. C. 192.

${ }^{4}$ Deely, J. Basic of semiotics / Univ. of Tartu. Tartu : Tartu Univ. press, 2005. XXXIII. 268 p. 
Досягнення найкращих навчальних результатів студентів у межах навчальної програми під час вивчення психології та педагогіки у вищій школі можливе за використання їхніх творчих спеціалізованих навичок як майбутніх спеціалістів творчого напряму мистецтвознавства. У процесі навчальної роботи із групою викладач взаємодіє з окремими групами студентів за індивідуальними темами або загально, враховуючи їхній аналітичний досвід та особливості їхніх творчих можливостей. Слід створювати психолого-педагогічні умови для розвитку не тільки всіх загалом, а й кожного окремо. Це відповідна організаційна форма навчального процесу, коли вибір способів, прийомів, темпу навчання зумовлюється індивідуальними особливостями моделювання образно-логічних схем у навчальній діяльності студентів.

\section{2. Пояснювальні моделі у вигляді образно-логічних схем}

Виконання моделювання у вигляді образно-логічних схем малими творчими групами студентів робить інформативний образ досліджуваного явища ціліснішим і повнішим. Цю техніку моделювання ми застосовували для вивчення складних явищ життя людини: потенціалу iii буття, обдарованості, компетентності, життєвого шляху тощо.

Образно-логічні схеми урізноманітнюють інструментарій для сучасного викладання навчальної дисципліни за рахунок численних ілюстраційних, анімаційних і творчих презентаційних можливостей. Інтерактивні елементи та вбудовані додатки призначені для розвитку критичного мислення. Проведення дослідів та ілюстрування в «художньо-образному аналізі» пробуджують зацікавленість студентів і допомагають їм у засвоєнні навчального матеріалу.

Модель (від лат. modulus - міра, зразок, норма) - це об'єктзамінник, створений із метою відтворення за певних умов суттєвих властивостей об'єкта-оригіналу. Модель може бути представлена об'єктом, подібним до оригіналу, або описом об'єкта, тексту, комп'ютерної програми 5 .

Основним призначенням створення моделі у вигляді образнологічних схем із певної теми $\epsilon$ аналіз і синтез; їхня цілеспрямованість, спрощеність, повнота, адекватність. Модель вважається адекватною об’єкту-оригіналу, якщо вона 3 достатнім ступенем наближення на рівні розуміння системною аналітикою модельованого процесу відбиває закономірності процесу функціонування реальної системи використання «художньо-образного аналізу» у зовнішньому психологічному середовищі.

5 Словник української мови / АН УРСР. Інститут мовознавства ; за ред. І.К. Білодіда. Київ : Наукова думка, 1970-1980. Т. 4. С. 776. 
За цільовим призначенням моделі поділяються на теоретикоаналітичні, що використовуються під час дослідження загальних властивостей i закономірностей певних процесів, i прикладні, які застосовуються у розв'язанні конкретних задач (моделі аналізу, прогнозування, управління).

Відповідно до загальної класифікації моделей вони поділяються на функціональні та структурні, а також проміжні (структурнофункціональні). Типовими структурними моделями $\epsilon$ моделі зв'язків, побудованих на основі «художньо-образного аналізу». Прикладом функціональної може слугувати модель поведінки студентів в академічній групі. За способами відображення чинника часу схеми, які мають «художньо-образний аналіз», поділяються на статичні та динамічні.

Моделі психологічних процесів у «художньо-образному аналізі» надзвичайно різноманітні за формою та відтворенням залежностей. Важливо виокремити клас лінійних моделей, що поширилися завдяки зручності їх використання. Відмінності між лінійними та нелінійними моделями $є$ суттєвими не лише $з$ погляду навчання, а й у теоретичному плані, адже багато залежностей мають принципово нелінійний характер.

Активне використання моделювання у вигляді образно-логічних схем на основі «художньо-образного аналізу» дають теоретичне пояснення сутності предмета дослідження та його зв'язків. Наприклад, у вивченні типів темпераменту спостерігається тенденція до індивідуалізації особистісних структур, що простежуються на рівні характеру. Інтеграція тенденцій до психологічної індивідуалізації й уніфікації змісту психічного може стати побудовою моделі у вигляді образно-логічних схем психічних процесів i станів. Основними характеристиками відкритої типології може бути характеристика, пов'язана із процесуальним способом побудови типології, коли кожний наступний етап ставить низку операційних і теоретичних питань, які потребують узагальнення i конкретного визначення. Характеристика передбачає розкриття особливостей кожного типу в системі всіх інших. Така типологія відображає системний підхід до вивчення психічних явищ як багатомірних i багаторівневих феноменів. Основою є виявлення подібності, відмінностей і спільності (тобто узагальнення) сукупності явищ, виокремлених у процесі виконання і побудови схем, а потім ідентифікація (тобто узагальнення нового рівня) 3 ідеалізованою моделлю «художньо-образного аналізу» досліджуваного явища. Це теоретичне з'ясування сутності предмета дослідження, що може мати прогностичний характер і стає засобом конкретизації та доповнення деталями первинного визначення предмета.

Метою моделювання у вигляді образно-логічних схем на основі «художньо-образного аналізу» $\epsilon$ здобуття, обробка, представлення і використання інформації про об'єкти вивчення. Тобто властивості та 
якості, поведінка об'єкта за певних умов $є$ важливою складовою частиною проектування моделі у вигляді образно-логічної схеми та включає процес аналізу та порівняння схем, створених різними творчими групами. Цілеспрямованість побудови моделі полягає в тому, що вона завжди будується з певною метою: які властивості певного явища вважаються істотними та є проекцією об'єктивної реальності під певним аналітичним кутом зору.

Аналіз системи співвідношень певних понять у вигляді образнологічних схем дозволяє отримати відповідь на питання про характеристику об'єкта. Поєднання простих елементів дають еквівалентну схему будь-якої складності у вигляді образно-логічних зв'язків, підтверджують ефективність застосування інноваційних методів навчання. Головним досягненням індивідуально-орієнтованого навчання $є$ те, що воно дозволяє повністю адаптувати зміст, методи та теми навчальної діяльності, присвячені певним психологічним особливостям, стежити за їхньою під час вирішення конкретних завдань; стежити за рухом від незнання до знань, вчасно вносити необхідні корективи в діяльність того, хто навчається.

Для активізації творчої навчально-пізнавальної діяльності студентів необхідне: формування змістових мотивів навчально-пізнавальної діяльності, професійного самовизначення, динамічний процес орієнтації особистості в розвитку та самореалізації потенційних можливостей, формування адекватних професійних намірів і планів, сприймання реалістичного образу себе як професіонала.

Застосування інноваційних методів навчання у процесі вивчення психологічних дисциплін допомагає здійснювати його ефективно, розвивати креативність і аналітико-логічне мислення в навчанні через творчість. Створення психологічних умов із використанням інноваційних методів і прийомів навчання активізує навчальну та пізнавальну діяльність, характеризується єдністю мотиваційних, інтелектуальних, процесуальних, емоційно-вольових процесів i формується в навчальному процесі, який є двостороннім і залежить від суб'єкт-суб'єктної взаємодії. Моделі, створені за іншої психологопедагогічної тематики, теж будуть різними. Це характерно для складних систем, у яких кожна проекція виділяє суттєве для певної мети $з$ безлічі несуттєвого.

\section{3. Умови активізації творчої}

\section{навчально-пізнавальної діяльності студентів}

Задача моделювання образно-логічних схем полягає в тому, що для заданого об'єкта потрібно підібрати такий опис і логічно-образну схему, використовуючи «художньо-образний аналіз», що повною мірою відображала б уже методологічно визнану мету моделювання. Доцільно виділити в об'єктах моделювання елементи, які 
розглядаються як неділимі одиниці. Повнота моделі полягає в тому, що вона має відображати всі істотні дані 3 погляду мети моделювання, характерні для предмета вивчення властивості. Узагальнюючи навчальний матеріал за допомогою «художньо-образного аналізу», викладач повинен звертати увагу на найважливіші ознаки предметів, явищ, процесів, добирати варіанти, які найповніше розкривають істотні ознаки явищ і понять.

Скінченність моделі визначає те, що модель відтворює кількість властивостей і їхніх відношень і через це завжди є більш простою, ніж підручник.

Сучасна система організаційних форм навчання у США поєднує заняття у великих аудиторіях з індивідуальними заняттями в малих групах, а лекції - 3 використанням сучасних технічних засобів (телебачення, ЕОМ та ін.) Для великих груп у 100-1500 чоловік читають висококваліфіковані викладачі, професори, а малі групи в 10-15 чоловік обговорюють матеріали лекції, ведуть дискусії. Індивідуальна робота проводиться в кабінетах, лабораторіях. На лекційні заняття відводиться 40\%, на заняття в малих групах $-20 \%$; на індивідуальну роботу в кабінетах і лабораторіях $-40 \%$. Класів як таких немає, а склад малих груп непостійний. У 1919 р. в м. Дальтон (США) Е. Паркхарст спробував замінити класно-урочну систему індивідуальною роботою 3 кожним учнем із наступною роботою кожного учня за планом, виробленим спільно 3 педагогом. Учні отримали можливість просуватися у вивченні шкільних програм кожен своїм темпом. Першу половину дня працювали самостійно на основі робочих посібників, без усякого розкладу, у другій половині - заняття у групі за інтересами. Заборонялося збиратися у групах або парах, щоб якісь питання чи теми обговорювати або опрацьовувати спільно. Такий «метод проектів» застосовувався в багатьох школах і вишах у $20-x$ рр.; сьогодні шкільна практика знову звертається до нього.

Це комплексний навчальний метод, який дозволяє індивідуалізувати навчальний процес, дає можливість проявити самостійність у плануванні, організації та контролі своєї діяльності. Ще збір колекції власної бази цікавих прийомів, знахідок, власних засобів наочності, дидактичних матеріалів, продуктивних технологій, що відображають успіхи або досягнення з тієї чи іншої проблеми, індивідуальної творчої теми. Включаються зразки робіт у письмовому чи друкованому вигляді, відеоматеріали, зразки робіт, фотографії компонентів навчального

${ }^{6}$ Слободянюк Т.Б. Інновації в педагогічному процесі: метод моделювання та образно-логічні схеми в навчальній роботі. Integration of New Knowledge, Research and Innovation Across Europe : Матеріали I міжнародної науково-практичної конференції (м. Київ, 23-25 квітня 2020 р.). Київ : Державний університет телекомунікацій, 2020. С. 58. 
процесу, ведення щоденника рефлексії, в якому обмірковується власний досвід, види діяльності, визначаються нові шляхи втілення творчих планів, прогнозуються стратегії для покращення діяльності, успіхи та невдачі, комунікативні стратегії.

У сучасній вітчизняній педагогічній практиці та теорії найбільш яскравими прикладами технологій індивідуалізації навчання $є$ такі: за типом управління (система «репетитор»); за організаційними формами (альтернативні, академічні, індивідуально-групові). Поширення набутого й апробованого перспективного досвіду викладача відбувається шляхом оприлюднення його індивідуальних наробок на науково-практичних конференціях, педрадах, методичних об'єднаннях, у періодичній пресі, інтернет-ресурсах (розміщення матеріалів на власному сайті, web-сторінці) тощо; організація майстер-класів, участь у наукових, проблемних семінарах, творчих дискусіях, методичних мостах, ділових і рольових іграх, навчальних тренінгах тощо, звітах про виконану роботу; опрацюванні матеріалів фахової періодики, спілкуванні із творчими особистостями, колегами тощо.

У різних науках може вивчатися той самий об'єкт, методи однієї науки використовуються для вивчення об'єктів інших наук, різні науки використовують одну і ту саму теорію для вивчення різних об'єктів. Зв'язки відіграють роль дидактичної умови підвищення ефективності навчального процесу, а міжнаукові зв'язки - ефективності наукової діяльності студентів. Одним зі шляхів реалізації міжнаукового підходу може бути проектування комплексу міждисциплінарних завдань на навчальні дослідження. У процесі розвитку інтеграційних педагогічних принципів відбувається формування нового типу пізнання - пізнання інтегрального типу.

Застосовуючи інтеграційні педагогічні принципи у предметномодульній системі освіти, викладач може створювати особисті авторські інтегровані курси. Дисциплінарна глибина необхідна для вивчення цих складних питань, Говард Гарднер називав це «синтез розуму». Уявлення про знання можна назвати «пізнавальною позицією» за емпіричною і теоретичною частинами роботи.

Студенти можуть сприймати різні епістемічні позиції (гносеологія розгортає свої уявлення навколо позиції «суб'єкт - об'єкт», а для епістемологї базовою є позиція «об'єкт - знання»). Механізм свідомості, що бере участь у процесі пізнання, враховується опосередковано, через наявність у знанні інтенціональних зв'язків (номінації, референції, значення та ін.).

Ïї складовими частинами $є$ тематичний компонент, що вказує, яку функцію виконують предметні знання у навчанні; операційна компонента, що визначає уміння студентів із дисципліни; семантична компонента, яка виокремлює семантичний зміст; процедурна компонента, що передає порядок дій у процесі виконання навчальних 
завдань. Таким чином, під час смислового запам'ятовування більшого значення набуває процес мислення та засіб перетворення інтуїтивних представлень у логічний, раціональний план мислення. Студенти прагнуть зрозуміти, запам'ятати, встановити зв'язок нового матеріалу із попереднім, невідомого із тим, що вже знайоме.

Моделювання у вигляді образно-логічних схем включає процес осмисленого запам'ятовування, низку логічних операцій (смислове групування; виділення смислових зв'язків), залучаючи їх до визначення смислових відношень, складання плану тощо. Весь накопичений матеріал, змістовна постановка задачі моделювання, додаткові вимоги до реалізації моделі оформлюються у вигляді технічного завдання на проектування та розробку моделі.

Осмислення й узагальнення зазвичай грунтуються на достатніх наукових знаннях, забезпечують широке використання порівняння, аналогії та доведення. Іноді це досвід декількох суперечливих відповідей і альтернативні висновки (на відміну від консервативного досвіду). Така множинність $є$ ключовою особливістю міждисциплінарного викладання і навчання студентів ${ }^{7}$.

\section{4. Формування методологічних навичок проектування логічно-образних схем}

У застосуванні логічно-образного моделювання значення мають загальні методологічні навички проектування і відповідний рівень знань. «Художньо-образний аналіз» і навчальна діяльність на його основі передбачають ширші, ніж традиційні, дисциплінарні можливості, їхню глибину. Вивчати теорію, використовуючи навички розуміння, перекладу та синтезу декількох дисциплінарних методів і перспективи це корисна модель «художньо-образного аналізу», процес розділення об'єкта на складові частини та подальшого синтетичного об’єднання їх у певну систему. Передбачається перелік стандартних завдань, використання декількох способів пізнання, поєднання бачення та розуміння природи знань, вміння інтегрувати, синтезувати, визначати баланс, що містить знання 3 дисципліни для того, щоб зробити щось більше. «Художньо-образний аналіз» передбачає синтез або баланс різних позицій як більш глибоке розуміння та збалансоване рішення або продукт, який творчо підходить до різних думок.

3 іншого боку, якщо студенти проходять складні позиції моделювання для відображення у кількох перспективах, вони повинні побачити певний зміст навчальної проблеми та стикаються iз можливістю займатися тим, що Дж. Дьюї називає «діалогічне рефлексивне мислення», або обгрунтованими твердженнями. Для цього

${ }^{7}$ Deely, J. Basic of semiotics / Univ of Tartu. Tartu : Tartu Univ. press, 2005. XXXIII. 268 p. 
можна використати методику виявлення зв'язків у масиві емпіричних і теоретичних методів, які мають інтегративну основу в загальній системі підготовки фахівця. Освітній процес орієнтується на студентів як на майбутніх фахівців. Відбувається формування понять у професійно-освітньому процесі фахівця як особистості, інтенсифікація навчання студентів, побудова навчально-виховного процесу на основі сучасних психолого-педагогічних технологій, керівництво навчально-виховним процесом викладачами, котрі володіють професійною майстерністю та високою педагогічною культурою викладання. Комплекс завдань розробляється викладачами та вимагає додаткового часу на організацію освітнього процесу. За успішної спільної роботи викладачів, що використовують логічний «художньо-образний аналіз» і персоніфіковані завдання, зростає інтерес студентів до дослідницької діяльності за рахунок більш високої мотивації. Необхідно визначитися, які повинні бути результати, як забезпечити належний рівень знань і чи забезпечить знання навчальний курс «Художньо-образний аналіз». Творча робота можлива також як результат самостійного навчання 3 обов'язковим цілепокладанням і врахуванням індивідуальних можливостей, здобутків, інтересів студентів, а інноваційний підхід забезпечить вдосконалення очікуваного рівня отриманих знань студентами. Аналітична діяльність спрямовується на досягнення конкретних цілей вирішуваних завдань (результатів у практичній діяльності). Робота в міжкурсовий період може бути врахована під час атестації педагога (кредити у формі післякурсових творчих завдань, участь у проведенні семінарів, творчих столів, наукових досліджень, розробка та публікація навчальнометодичних матеріалів, авторських програм, робота у складі творчих груп, участь у професійних конкурсах тощо; вибір спецкурсів; самоосвітня діяльність (епізодична і планова), саморозвиток, пошук шляхів професійної самореалізації; акумуляція застосування на практиці результатів інноваційного досвіду та наукових досліджень; апробація сучасних науково-методичних концепцій, виявлення та впровадження освітніх продуктивних технологій навчання і виховання, які допоможуть виконувати навчальні завдання). Необхідне переведення навчального процесу на технологічний рівень, тобто попереднє проектування процесу навчання з урахуванням дидактичних цілей і заданого рівня засвоєння; оптимальне поєднання фронтальної, групової, індивідуальної форм організації навчального процесу, застосування активних (інтерактивних, кооперативних) технологій навчання; складання плану самовдосконалення: вивчення передового досвіду колег, проведення відкритих занять, самоаналіз, обговорення відвіданих занять, введення у практику комплексу дидактичних матеріалів; апробація в інноваційному режимі ідей новаторів; створення авторської методики, технології; реалізація положень 
концепції на основі розробки й апробації авторської програми, навчального посібника; узагальнення власного досвіду, його систематизація й опис методичних прийомів.

\section{5. Досвід запровадження у навчальний процес схем «художньо-образного аналізу»}

За умови виконання завдань малими творчими групами аналіз визначення рівня засвоєння навчального матеріалу буде складнішим, але він визначиться під час семінарсько-практичних занять на основі презентування виконаних схем модульно-розвивальних завдань кожною творчою групою та забезпеченням роботи аналітичної групи «критиків». Під час заняття групи міняються ролями, що дозволяє на основі виконаних завдань і проведення аналізу поглибити й уточнити знання студентів, а також $\epsilon$ важливим моментом запровадження в навчальний процес активних методів і форм навчання. Використання у процесі навчальної роботи модульно-розвивальних завдань із залученням «художньо-образного аналізу» сприяе більш поглибленому і грунтовному засвоєнню навчального матеріалу, формує вміння оперувати свідомо психолого-педагогічною термінологією, отримуючи змістово-логічну цілісність і завершеність нових знань, закріплення уже відомих. У системі модульно-розвивального навчання створення схем «художньо-образного аналізу» використовується переважно малими творчими групами на практично-семінарських заняттях і під час підготовки різних видів виконання самостійних завдань. Модульні завдання передбачають детальне вивчення окремих питань, від яких залежить загальне вивчення курсу психології та педагогіки у вищій школі, сформованість знань щодо використання в навчальній діяльності сучасних педагогічних технологій навчання в межах кожного змістового модуля.

Виконання модульно-розвивальних завдань як самостійно окремими студентами, так і підгрупами формує у студентів уміння і навички самоосвіти та відповідну мотивацію і розуміння навчального матеріалу завдяки використанню навчально-методичної літератури, конспектів із лекційного курсу. Розв'язання таких завдань забезпечує активність навчальної діяльності в аудиторній і позааудиторній роботі, формує творчий підхід у прийнятті рішень, вміння розроблювати і застосовувати наукові обгрунтування в «художньо-образному аналізі», використовувати свідомо психолого-педагогічну термінологію, деталізувати поняття процесу навчання, поглиблювати свої знання. Функції педагога вбирають у себе функцію від інформаційно-консультативної до координуючої роботи. На цьому етапі відбувається систематизація навчального матеріалу, узагальнення, уточнення, в основі яких класифікація фактів, явищ, процесів. 
Закріплення й уточнення знань $є$ одним із завдань реалізації дидактичного принципу міцності засвоєння навчального матеріалу із застосуванням образотворчих вмінь.

Запам'ятовування навчального матеріалу починається 3 його сприймання й осмислення, проте цього недостатньо, щоб студенти вільно ним оволоділи. Слід навчати студентів запам'ятовувати, закріплювати в пам'яті навчальний матеріал за допомогою асоціації за схожістю.

Схожість об'єктів і їхня відмінність повинні бути відображені у свідомості студентів внаслідок спеціальних розумових операцій (аналізу, порівняння, узагальнення і т. ін.). Підхід до модульного навчання, яке розглядав проф. А.М. Алексюк, 3 погляду сучасних педагогічних технологій передбачає, що «для впровадження модульного навчання у практику вищої школи вкрай потрібні нові принципи комплектування тьюторських груп із кількістю студентів не більше 6-15 осіб». Тому в роботі над виконанням завдань «художньо-образного аналізу» із застосуванням образотворчих вмінь створювалися малі творчі групи 3 кількістю студентів не більше 5-6 осіб у кожній підгрупі.

Використовуючи в роботі всі найважливіші положення, що забезпечують цілісне розуміння понять, модульні завдання, включаючи «художньо-образний аналіз», були побудовані таким чином, щоб розуміння i засвоєння кожного модуля розпочиналося оглядовоустановчою лекцією. Далі планувалася і проводилася самостійна навчальна робота, яка складалася із 4-5 завдань різного спрямування, враховуючи попередній зміст навчальної діяльності та джерела, виділені у списку обов'язкової літератури для ознайомлення й опрацювання. Організаційно кожне модульне завдання полягало у виконанні певного обсягу завдань, відповідного засвоєння знань певного змістового модуля та вибіркової частини змісту навчання, сформованій як змістовий модуль. Вибіркова частина навчального матеріалу визначалася навчальною програмою і враховувалася як обов'язковий для засвоєння зміст навчальної дисципліни відповідно до вимог освітньокваліфікаційної характеристики як нормативної частини змісту навчання: змістові модулі із зазначенням їхнього обсягу, рівня засвоєння (врахування підготовки та підготовленості), а також затверджених форм із державної атестації. Тому до структури функціональних моделей процесу навчання були включені різні за змістом завдання. Наприклад:

\section{Змістовий модуль ІІ. Процес навчання у вищій школі.}

Тема № 2: Форми організації навчального процесу у вищій школі.

Завдання № 1. Змоделювати кольорові логічні схеми «художньообразного аналізу» 3 питань про форми організації навчального процесу та його функції у вищій школі. Робота малими творчими групами. Скласти письмове пояснення на звороті аркуша (15-20 хв); 
Завдання № 2. Презентація виконаних робіт представниками творчих груп. Аналіз, коментарі, роз'яснення магістрантами змісту на основі створеного «художньо-образного аналізу», покладеного в основу моделювання схем (20-25 хв);

Завдання № 3. I етап. Створення індивідуальних програм самоосвіти, самовдосконалення та професійного зростання. Спланувати обсяг самостійної навчальної роботи та чітко визначити ії завдання відповідно до курсу «Психологія та педагогіка вищої школи» (виконується позаудиторно, самостійна робота).

II етап. Обговорення, дискутування розроблених магістрантами планів самостійної роботи (виконується аудиторно). Прогнозування затрат часу на виконання проектів (20-25 хв).

Завдання № 4. Порівняльний аналіз навчальних планів із підготовки магістрів, включаючи різні спеціальності (2-3 зразки), для визначення співвідношення самостійної та інших видів роботи студентів. Спільне обговорення й обгрунтування викладача 3 магістрантами питань важливості збалансованого співвідношення різних видів роботи (аудиторних занять, самостійної роботи). Запис аргументів на дошці, в індивідуальних зошитах:

1) про роль і функціональне призначення різних форм роботи над змістом дисциплін, які викладаються у виші;

2) про адекватні форми організації, добір методів для роботи над змістом навчальної дисципліни.

Аналіз заняття та підведення підсумків.

Досвід роботи показав, що всі задіяні компоненти процесу навчання по-різному конкретизували навчальний матеріал відповідно до змодельованих завдань у межах однієї теми й однакової мети, а це означає, що в моделях методичного та технологічного рівнів виконання модульних завдань здійснювалося шляхом перенесення теоретичних i методичних положень у площину конкретних завдань. Цілеспрямованість у виконанні роботи - це орієнтація аналітичної діяльності на досягнення конкретних цілей вирішуваних завдань (результатів у практичній діяльності).

Модульні завдання, включаючи «художньо-образний аналіз», мають значний вплив на збагачення й уточнення багатьох психологопедагогічних понять, вирішення яких здійснювалося у творчих групах, стимулювало їхню активність. Тому потрібно зазначити, що використання розвивальних освітніх систем відбиває об'єктивну потребу у певному типі навчальної діяльності, створить механізми професійного саморозвитку i самовдосконалення, сприятиме переорієнтації освіти на ефективні технології навчання. Серед поставлених завдань контрольованого викладачем процесу виконання спланованого обсягу самостійної роботи з розв'язання тематичномодульних завдань слід назвати такі: доповнення і поглиблення знань із 
предмету; застосування здобутих знань; узагальнення і повторення вивченого матеріалу; удосконалення вмінь і навичок; розвиток творчих якостей, самостійності, цілеспрямованості; вироблення свого стилю розумової діяльності; формування вміння інтегрувати отримані знання 3 різних галузей науково-методичної підготовки та застосування їх відповідно до вимог.

\section{ВИСНОВКИ}

Використання в навчальній роботі логічно-образних схем модульнорозвивальних завдань із застосуванням образотворчих вмінь $\epsilon$ важливим засобом упровадження сучасних педагогічних технологій освіти та забезпечує високу якість засвоєння навчального матеріалу, сприяє розвитку логічного мислення, творчих здібностей та активного мотивованого процесу засвоєння знань, а також є одним із засобів пізнавальної діяльності, що визначають ефективність широкого застосування різноманітних форм, методів і засобів навчання у виші. Такі навчальні умови сприяють творчій уяві, усвідомленню студентами мети створення «художньо-образного аналізу» у вигляді схем із залученням їхніх професійно значущих здібностей. Це формує позитивно-активне мотивоване ставлення до реалізації власного творчого потенціалу, розуміння зображень психологічно-емоційних образів, розвиває інтелектуальну здатність аналізувати доречність використаних образів, застосовувати на практиці прийоми створення образів «уява - поняття», використовувати творчу уяву для створення оригінальних уроків і творчих завдань. У системі образотворчої освіти вищих навчальних закладів формування вмінь зі створення у навчальному моделюванні художніх образів має стати цілеспрямованим і педагогічно керованим процесом.

Це забезпечує розвиток системного мислення, здійснює управління процесом оперування системними поняттями, які відображають взаємозв'язок об'єктів (предметів думки) між собою. Викладання навчального предмета стає фактично особистісно-орієнтованим, що передбачає: наявність мотивації навчання для досягнення мети, комфортне освітнє середовище 3 використанням ефективних форм, методів і технік навчання з опорою на досвід, знання, уміння й навички студентів, наявність у студентів контролю над процесом свого навчання і досягненням успіху, потребу в самореалізації та достатність часу на засвоєння нових знань і вмінь. Інноваційний підхід завдяки моделюванню із застосуванням образотворчих вмінь забезпечує усвідомленість, спрямовану на особистісний розвиток майбутніх фахівців, їхню здатність до набуття нового досвіду на основі цілеспрямованого формування творчого i критичного мислення, рольового та імітаційного моделювання. 
Аналітичні методи моделювання шляхом створення «художньообразного аналізу» полягають у пошуку залежностей між їхніми психологічними характеристиками, однак при спрощенні дають можливості вивчити хоча б загальні властивості об’єкта.

Моделювання можна розглядати як зручнішу систему, що зберігає істотні риси навчальної проблеми. Здійснюється апроксимація (наближений опис однієї функції іншою) більш простою і зручною для практичного аналізу створеною логічно-образною моделлю, яка є результатом аналітичної діяльності студента в необхідні терміни, у зручному виді й у формі, призначеній для безпосереднього використання.

Метод моделювання дозволяє виключити необхідність значної кількості наочності, дає можливість скорочувати час на визначення й аналіз психологічної картини психічних процесів, поведінки об'єкта; аналізувати можливість застосування різних елементів впливу; отримувати різні характеристики та показники (кореляційні, чутливості).

Основна ідея модернізації системи вищої освіти полягає в тому, що ефективність навчання у вищій школі може бути поліпшена завдяки впровадженню продуктивних освітніх систем і технологій. Безперечно, у кожній конкретній ситуації необхідні актуальні для неї засоби оптимізації навчального процесу, що залежить від знань студентів, досвіду викладача, його уміння аналізувати та робити об'єктивні висновки.

Формування змісту дисциплін, пов'язаних із переробкою інформації, сприяє усвідомленню питань, що стосуються людського знання, ролі знання в житті суспільства, видів знання і способів його існування. Планування й організація проектів, вміння досягти результату, розвивати здібності - всього цього ми вчимо студентів, спираючись на їхні образотворчі уміння у межах навчальної програми, у т. ч. під час вивчення психолого-педагогічних дисциплін.

\section{АНОТАЦІЯ}

Підтверджено позитивний вплив застосування методики моделювання образно-логічних схем в інтегрованому навчальному курсі психології та педагогіки майбутніх спеціалістів із мистецтвознавства. Це робить навчання сучасним, цікавим і підвищує ефективність навчальної роботи. Моделювання у вигляді образнологічних схем за аналогією споріднене з комп'ютерним баченням логіки взаємозв'язків психологічних явищ. Використання моделювання у навчальних техніках «відтворення змісту» та «відтворення логіки пізнання» із застосуванням образотворчих умінь полягало в побудові «образу-моделі» психологічного явища або процесу, що характеризує систему природних, соціальних і духовних відносин. Завдяки вмінню малювання і кольоровим рішенням застосування інноваційних методів навчання дозволяє студентам - майбутнім спеціалістам із 
мистецтвознавства в образно-логічних схемах творчо відображати зміст навчального матеріалу. Метод моделювання дозволяє виключити необхідність значної кількості наочності, надає можливість скорочувати час на визначення й аналіз психологічної картини психічних процесів, поведінки об'єкта. Створення образно-логічних схем дає додаткові можливості для аналізу різних елементів психологічного впливу, більш детальних психологічних характеристик i змістових показників діяльності особистості (кореляційних, чутливості) 3 використанням творчих спеціалізованих навичок майбутніх спеціалістів творчого напряму мистецтвознавства. Виконання моделювання у вигляді образно-логічних схем малими творчими групами студентів робить інформативний образ досліджуваного явища ціліснішим i повнішим. Навчальний курс спрямований на формування логічних, критичних розумових умінь студентів, спонукає до постійного творчого пошуку в моделюванні, результатом чого $\epsilon$ створення логічно-образних схем за критеріями новизни, оригінальності й об’єктивної значущості.

\section{ЛІТЕРАТУРА}

1. Педагогічна енциклопедія. Москва, 1965. Т. 2. С. 201.

2. Словник української мови / АН УРСР. Інститут мовознавства ; за ред. І.К. Білодіда. Київ : Наукова думка, 1970-1980. Т. 4. С. 776.

3. Слободянюк Т.Б. Інновації в педагогічному процесі: метод моделювання та образно-логічні схеми в навчальній роботі. Integration of New Knowledge, Research and Innovation Across Europe : Матеріали I міжнародної науково-практичної конференції (м. Київ, 23-25 квітня 2020 р.). Київ : Державний університет телекомунікацій, 2020. С. 57.

4. Слободянюк Т.Б. Якість підготовки фахівців та ії відповідність європейським стандартам освіти. Науковий часопис / НПУ імені М.П. Драгоманова, 2010. С. 132-136.

5. Унт И. Индивидуализация и дифференциация обучения. Москва : Педагогика, 1990.

6. Deely, J. Basic of semiotics / Univ of Tartu. Tartu : Tartu Univ. press, 2005. XXXIII. 268 p.

\section{Information about the author:} Slobodianiuk T. B.,

Candidate of Pedagogical Sciences, Associate Professor at the Department of Culture and Social and Humanitarian Disciplines

National Academy of Fine Arts and Architecture 20, Voznesensky Uzviz str., Kyiv, 04053, Ukraine 